This paper appeared as:

D'Hertefelt, Sarah \& Jean-Christophe Verstraete. 2014. Independent complement constructions in Swedish and Danish: Insubordination or dependency shift? Journal of Pragmatics 60. 89-102.

\begin{abstract}
The aim of this paper is to analyse the grammatical status of independent complement constructions in Swedish and Danish, i.e. constructions introduced by the complementizer att or at but without an accompanying main clause. These constructions can be used with two main functions: to express the speaker's evaluation of a presupposed state of affairs, or to elaborate on an aspect of the preceding discourse. In recent literature on these and similar constructions in other languages, both types have been analysed as instances of the category of insubordination (Evans 2007), i.e. constructions that combine subordinate marking with main clause use. We will argue that this analysis works well for the 'expressive' type, but that it cannot account for some of the typical properties of the 'elaborative' constructions, like the fact that they are pragmatically dependent and inconsistent in their use of subordinate marking. As an alternative, we will show that elaborative constructions can be dealt with much more naturally in terms of an existing model of dependency shift in clause combining, like the subordinate-coordinate shifts observed for many other types of subordinators.
\end{abstract}

\title{
Keywords
}

Insubordination, complementation, Swedish, Danish, pragmatic (in)dependence, dependency shift 


\section{Independent complement constructions in Swedish and Danish: Insubordination or dependency shift?}

\section{1}

\section{Introduction}

In this paper, we analyse the grammatical status of independent complement constructions in Swedish and Danish, i.e. constructions introduced by a complementizer (att or at, respectively) but without an accompanying main clause, as in (1) and (2) below. In recent literature, such independent subordinate constructions have been analysed as instances of a broader pattern of 'insubordination' (e.g. Evans 2007 for the first typological survey; Gras 2011, ms. for Spanish; Verstraete et al. 2012 for Dutch), whereby formally subordinate constructions come to function as main clauses with their own independent semantics. Using data from Swedish and Danish, we argue that not all independent complement clauses can be analysed as insubordinate, and that some types are much more easily accommodated within models of dependency shift as we know them from the literature on clause combining (e.g. Günthner 1999; Goethals 2002; Verstraete 2005).
(1) At noget så katastrofalt kan COMP something so catastrophic can.PRS
ende så godt.
(DANISH, IC ${ }^{1}$ ) '[I can't believe] that something so catastrophic can end so well.'

(2) A: om vi skulle fråga våra eh förstaklassare här om dom vill ha betyg eller inte skulle dom inte fatta vad det handlade om vet inte hur vad betyg eller vad det $e$ (...) så det ju nånting som / andra lägger på

B: $j a$

$\begin{array}{lllllll}\text { A: att det } & \text { det } & \text { kommer ju sen atomatist i } \\ \text { COMP it } & \text { it } & \text { come.PRS PART afterwards automatically in } \\ \text { skolan } & \text { att } & \text { man får } & \text { betyg a då kommer den här / } \\ \text { school.DEF } & \text { COMP } & \text { one get.PRS grades }\end{array}$

\footnotetext{
${ }^{1}$ The data for this study come from the following sources: a corpus of Internet material (IC), the Swedish Göteborg Spoken Language Corpus (GSLC) and the Danish BySoc corpus. Constructed examples are marked with (C). We thank Karl Johan Sandberg (Göteborg University) and Peter Juel Henrichsen (Copenhagen Business School) for providing access to the two spoken corpora. To improve readability, part of the annotation of the context of relevant examples has been simplified. A key to the annotation formats for both spoken corpora can be found at their respective websites (see the reference section). Examples are glossed according to the Leipzig Glossing Rules (http://www.eva.mpg.de/lingua/resources/glossing-rules.php); abbreviations not found in the rules are PART 'particle' and TAG 'tag'. Morphological detail is kept to a minimum: we use the generalized convention of representing one-to-many correspondences between word forms and glosses with a dot between the different elements in the gloss (regardless of whether these represent morphological fusion in the system or a decision by the linguist not to provide morphological analysis).
} 
konkurrensen ännu mera in tror jag va

(SWEDISH, GSLC)

'A: if we were to ask our first-graders here if they want to have a diploma or not they wouldn't understand what it was about, don't know how what grades or what it is (...) so it's something that / others impose

B: yes

A: that it it then comes automatically in school that one gets grades and then this competition starts even more I think right'

The structures in (1) and (2) illustrate the two most important types of independent complement constructions (henceforth ICCS) in Swedish and Danish. First, ICCs can be used to express the speaker's evaluation of a presupposed state of affairs, as in example (1), where the speaker expresses their surprise that a catastrophic event can end so well. Second, ICCs can also be used to elaborate on something that was said before, as in example (2), where the speaker elaborates on their claim that striving for grades in school is imposed by the system. These two categories, which we will call expressive and elaborative, can be distinguished on the basis of a number of functional and formal properties, which we discuss in more detail below. ${ }^{2}$ Our investigation into the grammatical status of both types of ICCS will encompass the following questions. (i) Can expressive and elaborative ICCS be considered 'main clauses', in spite of their subordinate marking, or are they still 'dependent' in some sense? (ii) What is the status of the complementizer in such independent constructions? (iii) How did these constructions develop?

In this paper we argue that expressive ICCS are quite different from elaborative ICCs on all of these parameters, unlike what has been suggested in much of the recent literature on independent subordinate clauses (e.g. Evans 2007; Gras 2011, 2012, ms.; Verstraete et al. 2012), and more or less in line with the argument developed by Mithun (2008). One obvious candidate for the analysis of our two types of ICCs is the concept of insubordination, i.e. "the conventionalized main clause use of what, on prima facie grounds, appear to be formally subordinate clauses" (Evans 2007: 367). Evans (2007) captures the essential paradox of subordinate marking for a main clause by identifying a broad cross-linguistic pattern whereby structures that are formally marked as subordinate come to function as main clauses, possibly through a process of ellipsis of the main clause and subsequent conventionalization of interpretations at the level of the construction. At first sight, both types of ICCs seem to fit this pattern quite well. However, we will show that only expressive ICCs are a typical instance of insubordination, with clear subordinate marking and a

\footnotetext{
2 From a diachronic perspective, there were more types than just these two, for instance also an 'optative' type expressing the speaker's wishes (see, for instance, Lehti-Eklund 2001: 86 for such constructions in Swedish, and Hansen and Heltoft 2011: 769 for Danish), which is still found in other Germanic languages like German and Dutch (e.g. Panther and Thornburg 2011 for German, Verstraete et al. 2012 for Dutch). In this paper, however, we will limit ourselves to the two types of ICCs that are attested in present-day Danish and Swedish, i.e. the expressive and the elaborative types.
} 
conventionalized independent meaning. For elaborative constructions we can identify a number of properties that cannot easily be dealt with within the framework of insubordination, like the fact that they are pragmatically dependent and inconsistent in their use of subordinate marking. As an alternative, we will use the mechanism of dependency shift, like the subordinate-coordinate shifts that are well-known from the literature on subordination (e.g. Günthner 1999, Verstraete 2005) or the more general mechanisms identified by Mithun (2008). These offer a much better model to deal with elaborative constructions, capturing precisely those features that are difficult to deal with in an insubordination account.

In developing our argument, we start out from a constructional perspective, taking pairings of meaning and form as our basic analytic unit (see, for instance, Goldberg 1995, 2006). We pay special attention to the way the different meanings of independent complement constructions are encoded by different types of formal marking. Naturally, our focus is on differences in subordinate marking, specifically word order and the status of the complementizer, which tie in directly to the main argument. More indirectly, we also draw on some discourse and conversation analytic work, especially in our discussion of elaborative constructions. The rest of this paper is organized as follows. In sections 2 and 3 we present a brief constructional description of both the expressive and the elaborative constructions, discussing their typical functional and formal characteristics. In section 4 we address the main question of this paper, viz. which frameworks are best suited to account for these two types, appealing to two mechanisms from the domain of clause combining, i.e. insubordination and dependency shift. Section 5 addresses some implications of this study for further research.

\section{Expressive constructions}

Expressive ICCs like example (1) above and examples (4) and (5) below are used to express the speaker's evaluation of or reaction to a presupposed state of affairs (henceforth SoA). In example (1), repeated below as (3), the speaker expresses their surprise that something catastrophic can still end well, in example (4) below the speaker is amazed that someone still caught the train, and in example (5) the speaker expresses their annoyance at the fact that their friend never watches the time properly.

(3) At noget så katastrofalt kan ende så godt.. (DANISH, IC)
cOMP something so catastrophic can.PRS end.INF so well
'[I can't believe] that something so catastrophic can end so well.'

(4) Att du hann med tåget! (SWEDISH, Delsing 2010: 17)

COMP you make.PST with train.DEF

'[I'm surprised] that you caught the train!' 
(5) Gourmand väntar i baren på sin vän som kommer inrusande på La Famiglia en halvtimme för sent med ett knippe ursäkter till hands.

$\begin{array}{clllllll}\text { - Att } & \text { du } & \text { aldrig } & \text { kan } & \text { passa } & \text { tiden, muttrar } & \text { Gourmand. } \\ \text { COMP } & \text { you } & \text { never } & \text { can.PRS } & \text { watch.INF } & \text { time.DEF } & \text { mutter.PRS } & \text { Gourmand }\end{array}$

(SWEDISH, IC)

'Gourmand waits in the bar for his friend who rushes in at La Famiglia half an hour late with a bunch of excuses.

- Why can't you ever keep track of the time, mutters Gourmand.'

Constructions like these are well known from the literature, and have been described as 'exclamative' (e.g. Andersson 1982, Petersson 2011 and Delsing 2010), 'emotive' (e.g. Christensen 2009a, Christensen and Heltoft 2010, Heltoft 2011 and Hansen and Heltoft 2011: 1570) or 'expressive' (e.g. Teleman et al. 2010 vol. 4: 759). From a constructional perspective, we distinguish between two different subtypes of expressives, which in previous work we have labelled 'unexpected' and 'expected' (see Verstraete et al. 2012 on Dutch, and Verstraete and D'Hertefelt ms. for a broader Germanic analysis, including Swedish and Danish).

'Unexpected' expressives, like examples (3) and (4), express the speaker's surprise about an unexpected SoA. According to Delsing (2010: 32), this surprise effect is due to a mismatch between the presupposition (e.g. 'you caught the train' in example (4)) and what would be considered a more likely SoA (e.g. 'you didn't catch the train', which could be considered more likely, for example because the addressee left late). This mismatch in turn relates to the scalarity that is typical for these constructions, which signals that the actual SoA "lies at the extreme end of some contextually given scale" (Zanuttini and Portner 2003: 47), with more likely alternatives lying more towards the middle of the scale. Such scales can be explicit, i.e. marked by formal scalar markers like så 'so' in example (3), or they can be scales of 'implied probability' (Zanuttini and Portner 2003: 50), as in example (4). ${ }^{3}$

'Expected' expressive ICCs, by contrast, are used to express the speaker's annoyance at the continuing absence of something they want to happen, as in (5), where the speaker is irritated that their friend is never on time, or their exasperation at the recurrence of something they do not want to happen again, as in the following example, which describes the speaker's negative attitude towards the fact that someone always wears the same shirt:

\footnotetext{
${ }^{3}$ Not all linguists subscribe to the view that expressive constructions like these are scalar. See Petersson (2011) for a discussion of what he calls att-exclamatives in Swedish (and Danish, to a lesser extent) as polar rather than scalar.
} 
(6) Tænk $^{4}$ at han altid har den samme skjorte på!
think.IMP COMP he always have.PRS the same shirt on

(DANISH, IC)

'Why does he always wear the same shirt!'

'Expected' constructions typically contain expressions of necessity or inevitability, e.g. combinations of adverbs like always or never and modal verbs like must or can. In line with their semantics of expectedness, these structures are not scalar because they do not invoke a contrast with more likely alternatives on a scale.

Although the two types of expressives have typically been taken together in the literature, we believe that their differences in meaning (unexpected vs. expected) and in form (scalar vs. non-scalar) indicate that we are dealing with two different construction types, encoding two different types of 'expressive' meaning. We will not pursue this question in detail, however, as the distinction between the two, though relevant from a constructional point of view, is not immediately important for the basic question of this paper. Both can equally easily be analysed as a classic instance of insubordination, unlike the elaborative types to be discussed in the next section.

\section{$3 \quad$ Elaborative constructions}

The second function that ICCS can fulfil in Danish and Swedish has been illustrated in example (2) above, repeated here as (7), where the speaker uses an ICC to further elaborate on what they said before.

(7) A: om vi skulle fråga våra eh förstaklassare här om dom vill ha betyg eller inte skulle dom inte fatta vad det handlade om vet inte hur vad betyg eller vad det e (...) så det ju nånting som / andra lägger på

B: $\quad j a$

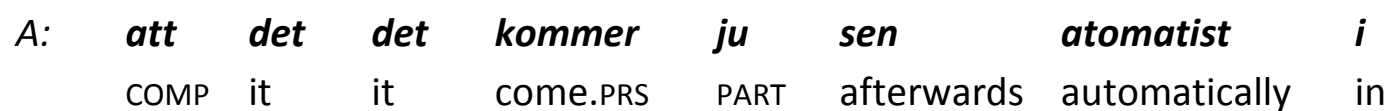

\footnotetext{
${ }^{4}$ In Danish, expressive ICCs of the expected type appear to require the marker tænk, which could be analysed as a grammaticalized form of the imperative of tænke 'to think' (see Delsing 2010: 33 on the presence of tænk in expressive ICCs; see also Hakulinen and Seppänen 1992: 527 and Heltoft 2007 on the development of such markers; for a discussion of the use of tænk as a 'regular', i.e. non-grammaticalized, imperative in argumentative constructions, see Christensen 2009b). The same form is frequently used in Danish with expressive ICCS of the unexpected type, but does not appear to be obligatory here. The Swedish cognate form tänk is also frequent in both types of expressive ICCs, but is never obligatory (see Teleman et al. 2010 vol. 4: 760). Further research would be needed here to investigate the precise function of this marker in the constructions under consideration, possibly in relation to other elements that can occur in the same position.
} 


$\begin{array}{lllll}\text { skolan att } & \text { man får } & \text { betyg å då kommer den här / } \\ \text { school.DEF COMP } & \text { one get.PRS } & \text { grades } & \\ \text { konkurrensen ännu mera in tror jag val } & & \text { (SWEDISH, GSLC) }\end{array}$

'A: if we were to ask our first-graders here if they want to have a diploma or not they wouldn't understand what it was about don't know how what grades or what it is (...) so it's something that / others impose

B: yes

A: that it it then comes automatically in school that one gets grades and then this competition starts even more I think right'

In their first turn, the speaker claims that first-year students are not aware of grades, and that grades are imposed on them by other people. The ICC in the next turn then elaborates on this claim, by explaining that attention to grades is something that 'comes automatically' in the school system, without the pupils' involvement. In constructions like these, the speaker uses an ICC to elaborate on or clarify an aspect of their previous discourse to guarantee proper understanding between speaker and interlocutor. From a conversational perspective, such elaborative ICCs typically function as turn increments, i.e. "nonmain-clause continuation[s] of a speaker's turn after the speaker has come to what could have been a completion point [...] based on prosody, syntax, and sequential action" (Ford, Fox and Thompson 2002: 16). These elaborative ICCs are used to "secure the proper interpretation of the turn just completed, now postcompleting it" (Lindström 2006: 97; see also Anward 2003; Lehti-Eklund 2001; Lindström and Londen 2001, 2008; and Lyngfelt 2003 for Swedish, and a brief reference for Danish in Jensen 2003).

Not all elaborative ICCs are used by speakers to elaborate on their own previous discourse, however: the following example illustrates that an elaborative ICC can also be used to expand on the interlocutor's previous turn:

(8) A: ja det kan jeg det kan jeg nemlig huske \# og jeg (rømmer sig) og så bemærket den når jeg så har været hjemme og været sammen med nogen $i k^{\prime} £ £$

$B$ at de så har bemærket det eller at du (uf) COMP they so have.PRS notice.PTCP it or COMP you

A: $\quad$ ja eller jeg selv har bemærket det $\quad$ (DANISH, BySoc)

'A: yes I can, you see I can remember that and I (clears throat) and so I have noticed it when I have been at home and have been together with someone

$B: \quad$ that they have noticed it or that you

A: yes or I myself have noticed it'

In this example, the ICC is used to rephrase what the interlocutor has just said, functioning as a way to check if the speaker has understood the interlocutor correctly. In the literature 
on conversation analysis, such structures have been called "formulations", i.e. constructions that "involv[e] a specific assertion of a specific understanding of some segment of talk and work to solicit a confirmation of that understanding by another" (Heritage and Watson 1980: 260). ${ }^{5}$ This is precisely what happens in our example (8): A first confirms 'yes' and then slightly modifies B's formulation ('or that I myself have noticed it'). The fact that formulations by the speaker are typically followed by either confirmations or disconfirmations by the interlocutor, the entire sequence thus functioning as a kind of 'adjacency pair' (Heritage and Watson 1980: 252, 254), is what distinguishes these constructions from increments, which do not require a 'second pair-part' by the interlocutor to either confirm or disconfirm this increment (Heritage and Watson 1980: 261).

Elaborative increments and elaborative formulations can be seen as two instantiations of a more schematic elaborative construction type. Regardless of the specific conversational status of these structures, what they all have in common is that the ICC elaborates on a preceding turn. This is also formally reflected in the use of some typical markers. These include markers like the (non-scalar) element så 'as a consequence' in (8), and discursive particles like Swedish $j u$ in (7) which is used to "demand the hearer's approbation and to establish rapport and harmony" (Aijmer 1996: 421, see also Hansen and Heltoft 2011: 10501051 on the Danish counterpart jo). Another marker that is used fairly frequently in elaborative ICCs is the Swedish particle liksom (Danish ligesom) 'like, so to say' (see example (13) in section 4 below), which signals that "the speaker wishes to correct or precise their word choice" (Londen 1997: 113, our translation). All of these markers raise awareness of the act of elaborating itself, either by strengthening the construction's descriptive, explanatory character $(s a ̊)$, by playing on the relation between speaker and hearer $(j u / j o)$ or by signalling that the utterance is only one way to express something (liksom/ligesom). These formal markers neatly fit in with the discursive explanatory functions of elaborative constructions.

Because they elaborate (as in example (7)) or rephrase (as in example (8)) something that was said before, elaborative ICCs do not really 'mean' something on their own but have to be interpreted in relation to the preceding discourse. These constructions can thus be considered pragmatically dependent on the discourse that precedes (Lindström and Londen 2008: 128). In the following section, we will argue that it is this pragmatic dependence that distinguishes elaborative ICCs from the expressive types, and at the same time also forms the main problem for analysing them as instances of insubordination.

\footnotetext{
${ }^{5}$ We thank a reviewer for drawing our attention to this work.
} 
One thing that the two types of ICCS discussed here have in common is the 'insubordination paradox' that Evans (2007) identifies: subordinate marking is used for a clause that does not appear to be dependent on a main clause. Accordingly, equivalents of these ICCs in other languages have been analysed as instances of insubordination, for instance in Gras (2011, 2012, ms.) for Spanish, Verstraete et al. (2012) for Dutch and Evans (2007) for a broad crosslinguistic sample. In this section, however, we will show that while expressive ICCs are a classic case of insubordination, elaborative ICCs are much less easy to fit into this model.

The rest of this section is organized as follows. First, we briefly introduce the phenomenon of insubordination, discussing what conditions a construction must fulfil to be considered insubordinate (section 4.1). Then, we investigate to what extent the criteria for insubordination are applicable to our two types of ICCs. In section 4.2, we show that they work well for expressive constructions, and in section 4.3 we show that they fail to account for some of the typical features of elaborative ICCS, for example their pragmatic dependence. We propose an alternative way to deal with such features, i.e. the mechanism of dependency shift as we know this, for instance, from subordinate-coordinate shifts in the literature on subordination (e.g. Günthner 1999; Goethals 2002; Verstraete 2005, 2007) or Mithun's (2008) work on the extension of dependency beyond the sentence. We support this argument by investigating variation in the presence of formal markers of subordination in elaborative constructions, specifically word order variation and complementizer detachment.

\subsection{Criteria for insubordination}

The term 'insubordination' was coined by Evans (2007: 367) to describe "the conventionalized main clause use of what, on prima facie grounds, appear to be formally subordinate clauses". This is meant to capture the paradox that in frequently cited structures like (9), we are dealing with a construction that is (i) conventionally used as a main clause, but (ii) formally marked as a subordinate clause.

(9) If you'll excuse me for a moment.

(ENGLISH, IC)

A first criterion for insubordination, then, is 'conventional main clause use'. Although Evans does not explain what exactly a 'conventional main clause' is, this criterion seems to imply that the construction in question needs to be syntactically independent, i.e. without a potential main clause present in the surrounding discourse.

A second criterion for insubordination is 'formal marking as a subordinate clause'. In Swedish and Danish, subordination is formally marked in two ways. First, the subordinate clause is usually introduced by a subordinating conjunction, like the complementizer at(t). Second, subordinate clauses display so-called 'subordinate' word order, which differs from 
the typical 'main clause' word order with respect to the position of the sentence adverb ${ }^{6}$. In main clauses, the adverb typically comes after the finite verb (FA-pattern), whereas it precedes the finite verb in subordinate clauses (AF-pattern). The following examples illustrate this difference:

$\begin{array}{lllll}\text { Han kommer } & \text { inte till festen } & \text { imorgon. } \\ \text { he come.PRS } & \text { NEG } & \text { to } & \text { party.DEF } & \text { tomorrow. }\end{array}$

'He is not coming to the party tomorrow.'

(11)

Det är hynd att han inte kommer till
festen

it be.PRES sad COMP he NEG come.PRS to party.DEF

imorgon.

(SWEDISH, C)

tomorrow

'It's a pity that he is not coming to the party tomorrow.'

In sum, in order to count as insubordinate Swedish and Danish ICCs need to be (i) syntactically independent, functioning as a 'main clause', and (ii) marked as subordinate by the complementizer $a t(t)$ and by 'subordinate' word order. In the following two sections, we examine to what extent these criteria are applicable to expressive and elaborative ICCs .

\subsection{Expressive constructions as an instance of insubordination}

The first condition for expressive ICCs to be considered insubordinate is main clause use, i.e. syntactic independence. The expressive examples in section 2 all occur without an accompanying main clause, and appear to be 'complete' on their own. Furthermore, expressive ICCs have also been analysed as 'main clauses' in much of the literature and in the standard grammars for both languages, with their own meaning and their own typical illocutionary force (see Teleman et al. 2010 vol. 4: 759 for Swedish, and Hansen and Heltoft 2011: 1570 for Danish). ${ }^{7}$

Expressive ICCS also meet the second condition that constitutes the paradox of insubordination, i.e. formal marking as a subordinate clause. All expressive constructions are introduced by the subordinating conjunction at(t), and word order is consistently the AFpattern typical of subordinate clauses, as has also been argued by Teleman et al. (2010 vol. 4: 10) for Swedish and by Hansen and Heltoft (2011: 1570) for Danish. In our examples

\footnotetext{
${ }^{6}$ We are aware that this traditional dichotomy between 'subordinate clause' and 'main clause' word order is not uncontested in the literature. This will be discussed in sections 4.2 and 4.3 , where we will explain how our data on elaborative constructions fit into this debate.

${ }^{7}$ However, there are some authors, like Petersson (2011), who argue that Swedish expressive ICCs are embedded under a covert main predicate.
} 
above, (3) and (4) lack a sentence adverbial and are therefore indeterminate for word order, but examples (5) and (6) clearly illustrate the 'subordinate' AF-pattern in expressive ICCs.

In this sense, expressive ICCs meet the two basic criteria for insubordination. As Evans (2007) showed, dealing with these structures as insubordination shows that they conform to a broad cross-linguistic tendency and are not just a strange or exceptional structure that is difficult to deal with. Apart from its broad cross-linguistic basis, the value of an insubordination analysis also lies in the diachronic hypotheses it offers (see Evans 2007: 368). In an insubordination analysis, expressive ICCs develop out of more or less 'regular' main + subordinate clause constructions, via ellipsis of a main clause that originally expressed the speaker's stance towards the SoA described in the at(t)-clause. For instance, a possible main clause for our example (3) would be the following:

(12)

$\begin{array}{lllll}\text { [Jeg } & \text { synes det } & \text { er } & \text { forbavsende] } \\ 1 & \text { think.PRS it } & \text { be.PRS } & \text { amazing }\end{array}$

$\begin{array}{llllllll}\text { At } & \text { noget så } & \text { katastrofalt } & \text { kan } & \text { ende så godt.. } & \text { (DANISH, IC) } \\ \text { COMP } & \text { something so } & \text { catastrophic } & \text { can.PRS } & \text { end.INF so } & \text { well } & \end{array}$
'[l can't believe] that something so catastrophic can end so well.'

This ellipsis-scenario is also what Evans (2007: 368) proposes for the development of insubordinate constructions in general. He argues that this kind of ellipsis goes hand in hand with conventionalization of the main clause meaning in the remainder of the construction. For expressive constructions, this would imply that the expressive meaning that was originally expressed by the matrix predicate (forbavsende 'amazing' in (12)) becomes conventionalized within the ICC, which in turn explains why expressive ICCs no longer 'need' an explicit main clause to be interpretable.

This diachronic scenario and the conventionalization it implies are indirectly confirmed by the fact that some authors no longer regard at( $t$ ) in expressive ICCs as a complementizer but rather as a 'frame' particle (Christensen 2009a: 121, our translation), or a 'subjective' particle (Hansen and Heltoft 2011: 1570, our translation), expressing the evaluation that was previously expressed by the matrix predicate. ${ }^{8}$ This is also reflected in discussions of word order in expressive ICCs in the literature. Heltoft (1992a, 1992b, 2011) and Christensen and Heltoft (2010: 93f, see also Christensen 2007) propose an analysis of Danish word order in terms of mood distinctions rather than the subordinate-main dichotomy. They argue that

\footnotetext{
${ }^{8}$ In the literature on similar constructions in Swedish, att is still considered a subordinator (Teleman et al. 2010 vol. 4: 760) or a complementizer (Delsing 2010 and Petersson 2011). However, Teleman et al. (ibid.) do indicate that att in what they call 'expressive main clauses' can be stressed, which is atypical for 'regular' complementizer use. Something similar has been argued to be the case for Danish at in expressive constructions.
} 
the FA-pattern is a declarative pattern, "signify[ing] that the content of the clause is informative" (Christensen and Heltoft 2010: 94), both in main and in subordinate clauses, whereas the AF-pattern is a neutral pattern, whose non-declarative character makes it suitable to be used in "factive and interrogative" subordinate clauses and "emotive" main clauses. Similar claims have been made for the distinction between 'main clause' and 'subordinate' word order in Swedish, by amongst other Andersson (1975), Julien (2007) and Brandtler (2008).

In sum, since expressive ICCS are conventionally used as main clauses but are marked as subordinate clauses, they can be considered a typical instance of insubordination. This has also been argued for similar constructions in other languages (e.g. Verstraete et al. 2012 for similar constructions in Dutch, Verstraete and D'Hertefelt ms. for a number of Germanic languages, and König and Siemund 2012 for a more general discussion of expressive insubordination).

\subsection{Elaborative constructions as an instance of dependency shift}

At first sight, elaborative ICCs also look like plausible instances of insubordination, and their equivalents in other languages have been analysed as such (e.g. Evans 2007; Gras 2011, 2012, ms.; Verstraete et al. 2012). In this section, however, we show that such an analysis is not justified for our Swedish and Danish data, since our elaborative ICCs do not meet the standard criteria for insubordination, both in terms of independence and in terms of subordinate marking.

The first criterion for insubordination is 'main clause use' or 'independence'. In section 3 we showed that elaborative constructions are intrinsically related to a previous move in discourse and that their interpretation therefore crucially depends on what was said before. Since elaborative constructions do not 'mean' anything in isolation, they cannot constitute an 'independent' move in discourse. In our view, this pragmatic dependence forms a major problem in considering these constructions 'independent' main clauses. We believe that a satisfying account of 'main clause use' should therefore not only include syntactic but also pragmatic independence. $^{9}$

On a pragmatic level, then, elaborative ICCs cannot be considered 'main clauses'. This analysis is strengthened even further if we look at the syntactic independence of elaborative ICCs. The elaborative constructions discussed in section 3 can all be considered syntactically independent in the sense that there is no main clause present in the surrounding discourse. However, there are also ambiguous cases, as the following example illustrates:

\footnotetext{
${ }^{9}$ If we apply this additional 'main clause' criterion to our category of expressive ICCs, it does not change their characterization as instances of insubordination. Although expressive constructions may react to something that was said before, this reaction in itself can constitute a wholly separate and independent move within the discourse, i.e. it can function on its own as an 'initiative' speech act (see also Petersson 2011: 181).
} 
(13) Når der bliver bevilliget en masse penge i en god sags tjeneste, så må der jo være noget professionalisme omkring det - at man ligesom har COMP one PART have.PRS

$\begin{array}{llll}\text { styr } & \text { på sine ting } & \text { (DANISH, IC) } \\ \text { control on one's thing.PL } & \end{array}$

'When a lot of money gets attributed to a so-called good cause, then there may be some professionalism around it - that one so to say has one's things under control.'

This structure is obviously elaborative in the sense that the complement construction serves to elaborate on something that was said before, by further explaining what the speaker meant by 'professionalism'. However, unlike with our previous elaborative examples, the ICC in (13) elaborates on one clearly identifiable nominal constituent rather than on a 'stretch of discourse'. Functionally, this ICC resembles so-called appositional clauses where a complement clause elaborates on an NP in close apposition, but formally it is different from such constructions in that it does not immediately follow the 'antecedent'. ${ }^{10}$ Like one of the elaborative constructions we distinguished in section 3, this ICC functions as an increment (see Ford, Fox and Thompson 2002: 16), but with a specifiable non-adjacent matrix. The question is, of course, to what extent this type of ICC can still be considered syntactically independent from this matrix element. Similar ambiguous cases of ICCS functioning as elaborative structures with an identifiable potential matrix are found quite frequently, as the following example illustrates:

(14) A: jag vill att dom ska ha fasta regler (...)

B: $\quad m^{\prime} m$

A: $\quad$ riktlinjer (följer ju dom)

B: $\quad m^{\prime} m$

A: ja att man eo strukturerad (...)

(SWEDISH, GSLC)

yes COMP one be.PRS structured

'A: I want them to have fixed rules [lit. want that they ...]

B: $\quad \mathrm{mm}$

A: directions (follow those)

B: $\quad \mathrm{mm}$

A: yes that one is structured'

This ICC elaborates on the speaker's preceding turn, but it could also be regarded as syntactically dependent on the preceding verb, i.e. the complement-taking vilja 'want'. Both

\footnotetext{
${ }^{10}$ Note that constructions like (13) cannot be considered relative clauses, as the conjunction used to signal relativization in Swedish and Danish is som rather than at( $t)$. In some cases, however, at(t) can be used 'pleonastically' after the relative pronoun (see ODS, SAOB, article 'at(t)').
} 
this and the previous example show that not all elaborative ICCS are clearly syntactically independent from what precedes. There is a thin line between elaborative constructions without a specifically identifiable matrix candidate in the surrounding discourse, like (7) and (8), and constructions that have an identifiable matrix and could be analysed as incremental alternatives to appositional or other constructions, like (13) and (14).

In sum, elaborative ICCs cannot be considered main clauses in their own right, since they are never pragmatically independent and not always syntactically independent. In this sense, they do not meet Evans' first criterion for insubordination. The main problem is that the complementizer $a t(t)$, which originally expresses syntactic dependence to a matrix on the propositional level, in elaborative constructions is used to signal pragmatic dependence on the discursive level. This is problematic within the insubordination analysis, but it can be accounted for very naturally in relation to another pattern that is well-known from the domain of clause combining, i.e. dependency shift. This mechanism describes cases in which conjunctions that typically mark subordinate dependency on the propositional level can also come to express dependencies on the discursive level, often going hand in hand with loss of clause-internal subordinate marking (see, amongst others, Küper 1991 and Günthner 1993, 1996, 1999 on German weil 'because' and obwohl 'although', Steensig 1998 on Danish fordi 'because', and Verstraete 2007: 181-186 more generally on Germanic and Romance). The following English examples illustrate such a shift:

(15) According to a spokesperson he does have tendinitis. It happened because he uses the muscles in his strumming arm too much.

(ENGLISH, CB ${ }^{11}$ )

(16) The shamed ex-spy, freed early after serving 14 years for offering secrets to the Russians, said: "I want to chill out and get used to freedom. Then I want to look for a job. I would consider anything, even being a postman - after all, a job's a job. I have to consider anything because who is going to employ me?" (ENGLISH, CB)

Example (15) illustrates the typical subordinate use of because: it specifies the reason for the content of the main clause proposition, i.e. the reason why someone has tendinitis. In example (16) on the other hand, because specifies the reason for the preceding assertion rather than the preceding proposition, i.e. the reason why the 'ex-spy' states that he has to consider anything. The originally subordinate conjunction because has thus undergone a shift from expressing dependency on the propositional level to expressing dependency on the discursive level ${ }^{12}$, just as is the case for the elaborative ICCs. The structurally different status of the second, discursive, type also has clear formal reflections, in this case in the

\footnotetext{
${ }^{11}$ These examples come from the Cobuild corpus (see references) and are cited in Verstraete 2004.

${ }^{12}$ See here also Lindström and Londen (2008: 147) on the difference between predication subordination and discourse subordination in Swedish för att 'because', så att 'so that' and men att 'but that' constructions.
} 
ability of the because-clause to take a non-declarative clause type, which is excluded for standard subordinate uses (see Verstraete 2007: 160ff on the relation between clause type and the analysis of 'subordinators').

We can find further evidence for analysing elaborative ICCs in terms of dependency shift if we look at their subordinate marking, i.e. word order and the status of the complementizer. We will start by discussing word order. In example (7) above, there is no sentence adverb either immediately preceding or following the finite verb, so word order is indeterminate. In example (8), the adverb/particle så precedes the finite verb, which is indicative of the 'subordinate' AF-pattern. If we look for further examples, we find other instances of elaborative constructions with the 'subordinate' AF-pattern, as in example (17), but also examples where the ICC shows the 'non-subordinate' FA-pattern, ${ }^{13}$ as in example (18):

(17) A: [...] nu bliver de ikke skrevet i hånden mere men det gjorde de jo engang ik'

B: $\quad j a$

A: $\quad$ om du kan skrive læseligt $f$ og hvad he-hvad hedder sådan gammel $£$ skrift altså karakteristisk

B: $\quad j a$

A: at det ikke bare erff omvendte S'er og COMP it NEG PART be.PRS reversed S.PL and

B: $\quad j a$

A: sådan nogen ting ik' (DANISH, BySOC) such some thing TAG

'A: now people don't write by hand anymore but they once did

$B$ : yes

A: if you can write legibly and what what do they call such old writing like characteristic

B: yes

A: that it's not just reversed S's and

B: yes

A: such things'

(18) A: [...] jobbet direktør det giver jo nok $\mathrm{f}$ en eller anden $\mathrm{f}$ prestige

B: $\quad j a^{\sim}$

A: at $f$ så bor du ikke i et eller andet COMP so live.PRS you NEG in one or other

\footnotetext{
${ }^{13}$ In the ICC in example (18) there is extraposition of the adverb så and subsequent inversion of the finite verb and the subject. Nevertheless, this type of word order has also been described as an instance of the more general FA-pattern, i.e. 'main clause' word order (see Lehti-Eklund 2001: 110).
} 
third-rate.house

'A: a job as manager well that implies some prestige

B: yes

A: that you don't live in some third-rate house'

Similar elaborative constructions with the FA-pattern have also been observed in Swedish, see for example Lehti-Eklund (2001: 110). ${ }^{14}$ Furthermore, Lehti-Eklund notes that in some cases elaborative ICCs do not just have 'main clause' word order, but can even have an interrogative or imperative clause type, as the following example illustrates:

(19) Regina: jå (eller) (.) men vi ska nu kolla för de finns- t- så kan man kolla me bildningsförbunde om di sku villa ge pengar

Nanna: $\quad m m$

Regina: (hh) så kan man kolla me den

Regina: hä: (.) kulturföreningen (.) XX kulturföreningen om di vill ge pengar (.) di ha nämligen pengar

Nanna: $\quad$ jå

Regina: $\quad$ så kan man kolla me:d ungdoms- (0.8) centralen

Regina:

att checka nu me dihär för nu sku de vara kiva att COMP check.IMP now with this kunna ge någå arvode (.) ） (SWEDISH, Lehti-Eklund 2001: 102)

'Regina: yes (or) but we will now check because there's so we can check with the education union if they would want to give money

Nanna: $\quad \mathrm{mm}$

Regina: $\quad$ so we can check with this culture union XX the culture union if they want to give money they happen to have money

Nanna: yes

Regina: $\quad$ so we can check with the youth central

Regina: [that] so check this now because it would be nice to be able to give some salary'

\footnotetext{
${ }^{14}$ At this point, it would also be interesting to compare our findings for elaborative at( $t$-constructions with similar discursive constructions where a non-embedded $a t(t)$-clause is preceded by a coordinating element, like plus 'plus' or men 'but', and where the at(t)-clause can also display the FA-pattern. See, amongst others, Julien (2009), Nørgård-Sørensen (2001) and Lindström and Londen $(2001,2008)$ for a more detailed discussion of such constructions.
} 
Once again, this is a feature that cannot be accounted for within the framework of insubordination: 'typical' subordinate complement constructions do not have 'main clause' word order, and they certainly do not combine with imperatives or interrogatives. Within the mechanism of dependency shift, however, 'main clause' word order and the use of nondeclarative clause types do not form a problem at all, but often serve as additional markers for the shift. Examples (15) and (16) have illustrated that shifts towards discursive uses go hand in hand with shifts in the internal structural possibilities of the clause. While the typical subordinate use of a subordinator combines with the unmarked declarative ${ }^{15}$, the discursive use of this element can also combine with a different sentence type, like an interrogative which also implies that the resulting structure can no longer be regarded as structurally subordinate (compare Goethals 2002, Verstraete 2004, 2007).

If we now turn to the second formal marker of subordination, i.e. the complementizer $a t(t)$, we can ask to what extent at(t) in elaborative ICCs can still be regarded as a subordinate complementizer, since it does not always indicate syntactic dependence and can even introduce 'main clause' sentence types. While the use of 'subordinating' conjunctions in independent uses always involves a certain paradox (as discussed earlier), there are strong indications that $a t(t)$ in Swedish and Danish elaborative ICCs may really be distancing itself from its 'original' subordinator use: in some elaborative constructions, at(t) can become prosodically detached from the proposition that it introduces. This was illustrated in example (18) above for Danish (where $f$ signals a pause), and is also attested in Swedish, as shown in the following example:

(20) A: men detta e ju faktiskt bara ETT av tv+ / ja åtminstone TVå tänkbara sätt att uppfatta kultur /

B: $m:$

C: $\quad m:$

A: att /e:h du ser det alltså som normer för // COMP eh you see.PRS it so as norm.PL for mänskligt beteende va / men du kan ju också uppfatta kultur human conduct TAG som / beteendet självt va (SWEDISH, GSLC)

'A: but this actually is only one out of tw- / yes at least two conceivable ways to interpret culture /

B: $\quad \mathrm{mm}$

C: $\quad \mathrm{mm}$

\footnotetext{
${ }^{15}$ As English does not have any word order difference between main and subordinate clauses, it uses the declarative as the 'default' or 'neutralized' option in 'regular' subordinate clauses (see Verstraete 2004: 824 for more details).
} 
A: that / eh so you see it as norms for // human conduct right / but you can also interpret it as / the conduct itself right

Because of its detachment from the following proposition, and because it can sometimes also combine with non-declarative clause types, it is questionable to what extent $a t(t)$ in elaborative ICCS can still be considered a 'subordinate' marker. Once again, this is problematic from the point of view of insubordination, but not from the point of view of dependency shift, where non-integrated discourse markers are often the endpoint of subordinators shifting away from subordinate construal (see Stenström 1998). In cases like (18) and (20), where $a t(t)$ is no longer prosodically integrated into the following proposition, this proposition is marked by FA-word order. However, in spite of its syntactic and prosodic detachment from the following proposition, at(t) still has a 'linking' function here: it functions as a discourse marker to signal that what follows provides a further elaboration of what precedes. An analysis of complementizers in elaborative constructions as discourse markers has already been proposed by various authors, e.g. by Lyngfelt 2003: 142 and LehtiEklund 2001: 81 for Swedish, and by Englebretson 2003: 123 and Seppänen and Laury 2007: 557 for similar constructions in colloquial Indonesian and Finnish respectively (see also Thompson 2002: 143 and Laury and Seppänen 2008: 153 for an analysis of the complementizer in such constructions as a 'linker'). In the Danish literature, moreover, the most recent grammatical description of at in Hansen and Heltoft (2011: 1657-1669) explicitly distinguishes between what they call 'internal' and 'external' types of $a t{ }^{16}$ This distinction is based precisely on the fact that some uses of at appear to be external to the clause with which they occur rather than being construed as part of it.

In sum, we have shown that the mechanism of dependency shift is a better model to deal with elaborative ICCs than the new concept of insubordination. Dealing with elaborative constructions in terms of this mechanism allows us to account for both the maintenance in dependency and the occasional availability of 'main clause' marking in these ICCs. Neither of these properties is easy to deal with within a model of insubordination. One final piece of evidence for this analysis relates to diachronic hypotheses. The occasional indeterminacy between appositional and 'independent' elaborative constructions, as illustrated at the start of this section in examples (13) and (14), may in fact offer a source construction for elaborative constructions within the model of dependency shifts. The appositional structure could then be the equivalent of the 'subordinate' type, and the 'independent' elaborative type the result of shifted dependency. It is much harder to account for the development of elaborative constructions with Evans' ellipsis pathway, as it seems quite arbitrary to reconstruct main clauses for constructions like (7) and (8), ${ }^{17}$ and even impossible for the

\footnotetext{
${ }^{16}$ We thank a reviewer for drawing our attention to this distinction.

${ }^{17}$ In our discussion of the development of expressive ICCS, we have shown that the ellipsis of the original main clause goes hand in hand with conventionalization of this main clause meaning in the remaining ICC. Whereas it
} 
cases where $a t(t)$ is no longer prosodically integrated or where it is followed by a declarative, imperative or interrogative clause type.

\section{Conclusions}

The aim of this study was to investigate the grammatical status of two types of ICCS in Swedish and Danish, i.e. expressive and elaborative constructions. We addressed this issue in terms of three main questions, relating to the 'main clause' status of ICCs in Swedish and Danish, the status of the complementizer in such constructions, and the diachronic development of these constructions.

As concerns the 'main clause' status of the two types of ICCS, we have shown that expressive constructions can be, and have often been considered main clauses in their own right. Elaborative constructions, on the other hand, are much more difficult to analyse as independent constructions since they are always dependent on the pragmatic level, and sometimes even syntactically. In answer to our second question, we have shown that at(t) has been reanalysed as a 'discourse marker' that can be followed by formally 'main clause' constructions in elaborative contexts, while it still has most of its subordinate features in expressive constructions, like prosodic integration within the following proposition and selection of the 'subordinate' AF-word order pattern. Third, we have shown that expressive constructions are compatible with Evans' developmental hypothesis for insubordination, i.e. it seems likely that these constructions developed via ellipsis of the main clause. Elaborative constructions, on the other hand, are not compatible with this hypothesis, but more likely developed via shifts in dependency.

To conclude, then, expressive and elaborative ICCs are quite different structurally, in terms of 'main clause' status and dependency, in terms of subordinate marking, and in terms of development. As a consequence, we need different models to analyse them. Evans' (2007) concept of insubordination works well for expressive constructions. They are syntactically and pragmatically independent but consistently use subordinate marking, which means that they meet all the criteria for a classic case of insubordination. Elaborative constructions, on the other hand, are not always entirely independent syntactically, and they are never independent pragmatically. Furthermore, they are not consistently marked as 'subordinate' clauses. As a consequence, elaborative constructions are better captured by mechanisms of dependency shift, as these are known from the literature on subordinators shifting from narrow (propositional) to wide (discursive) scope, with accompanying changes in the internal structure of the clause and the status of the subordinator.

would grammatically be possible to reconstruct a main clause for an elaborative structure like (7), i.e. something like [jag menar] att... '[I mean] that...' or [jag vill säga] att... '[I want to say] that...', it is hard to see how this meaning would then have 'conventionalized' in the remaining ICC. 
As argued in the introduction, many accounts of insubordination in specific languages include a 'discursive' category of insubordination, marking discourse relations that are very similar to the elaborative types described here. Given that these types equally maintain dependency relations, their analysis as insubordinate should perhaps be reconsidered. More generally, the importance of the distinction between syntactic and pragmatic (in)dependence has not yet been recognized in the literature on insubordination. We believe this distinction is important in defining the limits of insubordination and distinguishing it from other mechanisms within the general domain of clause combining. Furthermore, our argument about the need to distinguish between insubordination proper and discourse-level dependencies may be compatible with the diachronic argument developed by Mithun (2008), who shows that independent uses of subordinate clauses need not develop via a mechanism of ellipsis that breaks up dependency relations, but can also be due to a mechanism of extension of dependency relations beyond the clause.

\section{Acknowledgements}

Work on this paper was supported by project GOA/12/007, funded by the research council of the University of Leuven. Authorship is shared equally. We would like to thank the audiences of talks in Leuven, Copenhagen and Lund, as well as the editor and two anonymous reviewers for useful comments on earlier versions of this paper. We had very fruitful discussions with Tanya Karoli Christensen, Sune Sønderberg Mortensen, Eva Skafte Jensen, Marit Julien, Henrik Rosenkvist, David Petersson and Anna-Lena Wiklund on the nature of ICCs in both languages. For additional native speaker insights, we also gratefully acknowledge the help of Sune Sønderberg Mortensen and Eva Skafte Jensen for Danish, and Henrik Rosenkvist and Sara Gabrielsson for Swedish. Any remaining inaccuracies are of course our own responsibility. Sarah D'Hertefelt would also like to thank Academische Stichting Leuven for financial support of her stay in Copenhagen and Lund.

\section{Bio-notes}

Sarah D'Hertefelt is a researcher at the department of linguistics at the University of Leuven. Her research interests include complex sentence structure, comparative grammar, linguistic typology and pragmatics.

Jean-Christophe Verstraete is an associate professor at the department of linguistics at the University of Leuven. His research interests include clause combining, information structure, mood and modality, case systems, linguistic typology, and Australian languages. 


\section{References}

\section{Corpora}

BySoc Corpus, Danish Vernacular. Copenhagen University: LANCHART. Available online at http://bysoc.dyndns.org/index.cgi?.

Cobuild Corpus, Bank of English. More information at http://www.mycobuild.com/aboutcollins-corpus.aspx.

GSLC, Göteborg Spoken Language Corpus. Gothenburg University: Department of Linguistics. Available online at http://www.ling.gu.se/projekt/tal/index.cgi?PAGE=3.

\section{Literature}

Aijmer, Karin. 1996. 'Swedish modal particles in a contrastive perspective'. Language Sciences 18(1-2). 393-427.

Andersson, Erik. 1982. 'Om gränsen mellan huvudsats och bisats i svenskan [On the boundary between main clause and subordinate clause in Swedish]', in Mirja Saari and Marika Tandefelt (eds.) Svenskans Beskrivning 13. Helsinki University. 69-76.

Andersson, Lars-Gunnar. 1975. Form and function of subordinate clauses. Gothenburg Monographs in Linguistics 1. Gothenburg University.

Anward, Jan. 2003. 'Att [That]'. Språk och Stil 13. 65-85.

Brandtler, Johan. 2008. 'On the structure of Swedish subordinate clauses'. Working Papers in Scandinavian Syntax 81. 79-97.

Christensen, Tanya Karoli. 2007. Hyperparadigmer: en undersogelse av paradigmatiske samspil $i$ danske modussystemer [Hyperparadigms: A Study of Paradigmatic Interactions in Danish Mood-Systems]. PhD-dissertation. Institute for Culture and Identity, Roskilde University center. Available online at http://rudar.ruc.dk/bitstream/1800/2993/1/Afhandling som bog\%5B2\%5D.pdf (last accessed 13/06/2013).

---. 2009a. 'Hvem der bare havde en hund! - om emotive sætninger i dansk [If only one had a dog / 100 DKK - On emotive sentences in Danish]', in Ken Fard, Alexandra Hosting et al. (eds.) Sprogvidenskab i glimt. Odense: Syddansk Universitetsforlag. 121-124.

---. 2009b. 'Tag nu bare økomælken. Om imperative og modalpartikler i dansk' [Just take organic milk. On imperatives and modal particles in Danish], in Rita Therkelsen and Eva Skafte Jensen (eds.) Drammatiken i grammatiken. Festskrift til Lars Heltoft. Roskilde: Roskilde University. 51-67.

Christensen, Tanya Karoli and Lars Heltoft. 2010. 'Mood in Danish', in Björn Rothstein and Rolf Thieroff (eds.) Mood in the languages of Europe. Amsterdam: John Benjamins. 85102.

Delsing, Lars-Olof. 2010. 'Exclamatives in Scandinavian'. Studia Linguistica 61(1). 16-36.

Englebretson, Robert. 2003. Searching for Structure. The problem of complementation in colloquial Indonesian conversation. Amsterdam: John Benjamins. 
Evans, Nicholas. 2007. 'Insubordination and its uses', in Irina Nikolaeva (ed.) Finiteness. Theoretical and empirical foundations. Oxford: Oxford University Press. 366-431.

Ford, Cecilia, Barbara Fox and Sandra Thompson. 2002. 'Constituency and the grammar of turn increments', in Cecilia Ford, Barbara Fox and Sandra Thompson (eds.) The language of turn and sequence. Oxford: Oxford University Press. 14-38.

Goethals, Patrick. 2002. Las conjunciones causales explicativas en castellano. Un estudio semiótico-lingüístico. Leuven: Peeters.

Goldberg, Adele. 1995. Constructions. A Construction Grammar approach to argument structure. Chicago: University of Chicago Press.

---. 2006. Constructions at work: the nature of generalization in language, Oxford University Press.

Gras, Pedro. 2011. Gramática de construcciones en interacción. Propuesta de un modelo y aplicación al análisis de estructuras independientes con marcas de subordinación en español. Barcelona: Barcelona University. Available online at

http://www.tesisenred.net/handle/10803/1716 (last accessed 05/06/2013).

---. 2012. 'Entre la gramática y el discurso: Valores conectivos de que inicial átono en español', in Daniel Jacob and Katja Ploog (eds.) Autour de que. El entorno de que. Frankfurt am Main: Peter Lang.

---. Ms. 'Revisiting the functional typology of insubordination. Que-initial sentences in Spanish'.

Günthner, Susanne. 1993. Diskursstrategieen in der Interkulturellen Kommunikation. Analysen deutsch-chinesischer Gespräche. Tübingen: Max Niemeyer.

---. 1996. 'From subordination to coordination? Verb-second position in German causal and concessive constructions'. Pragmatics 6. 323-356.

---. 1999. 'Entwickelt sich der Konzessivkonnektor obwohl zum Diskursmarker? Grammatikalisierungstendenzen im gesprochenen Deutsch'. Linguistische Berichte 180. 409-444.

Hakulinen, Auli and Eeva-Leena Seppänen. 1992. 'Finnish kato: From verb to particle'. Journal of Pragmatics 18. 527-549.

Hansen, Erik and Lars Heltoft. 2011. Grammatik over det danske sprog [Grammar of the Danish language]. 3 vol. Odense: Syddansk Universitetsforlag.

Heltoft, Lars. 1992a. 'The topology of verb second and SVO languages. A study in the sign functions of word order', in Michael Herslund (ed.) Word order: Two studies on central issues in the syntax of Danish and French. Copenhagen Studies in Language 15. Copenhagen: Handelshøjskolens Forlag. 13-64.

---. 1992b. 'Topologiens plads i en sprogteori' [Topology's place in a language theory], in Frans Gregersen (ed.) Lingvistisk Festival. Sprogvidenskabelige Arbejdspapirer fra Københavns Universitet 2. 67-98. 
---. 2007. 'Subjektive partiklers grammatikalisering i nyere dansk - eksemplet sikke [The grammaticalization of subjective particles in present-day Danish - the example of sikke]'. Danske Studier 102. 17-42.

---. 2011. 'Word order change as grammaticalisation. Paradigm structure and change in Scandinavian', in Jens Nørgård-Sørensen, Lars Heltoft and Lene Schøsler (eds.) Connecting Grammaticalisation. Amsterdam: Benjamins. 171-235.

Heritage, John and Rod Watson. 1980. 'Aspects of the properties of formulations in natural conversations: Some instances analysed'. Semiotica 30(3/4). 245-262.

Jensen, Anne. 2003. Clause linkage in spoken Danish. PhD-dissertation, Copenhagen University.

Julien, Marit. 2007. 'Embedded V2 in Norwegian and Swedish'. Working Papers in Scandinavian Syntax 80. 103-161.

---. 2009. 'Plus(s) at(t) i skandinaviska - en minimal matris [Plus(s) at(t) in Scandinavian - a minimal matrix]'. Språk \& Stil 19. 124-141.

König, Ekkehard and Peter Siemund. 2012. 'Satztyp und Typologie', in Jörg Meibauer, Markus Steinbach and Hans Altmann (eds.) Satztypen des Deutschen. Berlin: Mouton de Gruyter.

Küper, Christoph. 1991. 'Geht die Nebensatzstellung im Deutschen verloren? Zur pragmatischen Funktion der Wortstellung in Haupt und Nebensätzen'. Deutsche Sprache 19. 133-158.

Laury, Ritva and Eeva-Leena Seppänen. 2008. 'Clause combining, interaction, evidentiality, participation structure, and the conjunction-particle continuum. The Finnish että', in Ritva Laury (ed.) Crosslinguistic studies of clause combining. The multifunctionality of conjunctions. Amsterdam: John Benjamins. 153-178.

Lehti-Eklund, Hanna. 2001. 'Om att som diskursmarkör [On att as discourse marker]'. Språk och stil 11. 81-118.

Lindström, Jan. 2006. 'Grammar in the Service of Interaction: Exploring Turn Organization in Swedish'. Research on Language and Social Interaction 39(1). 81-117.

Lindström, Jan and Anne-Marie Londen. 2001. 'men att de öppnades ju nog en ny värld för mej. Kombinationen men att - en ovårdad och onödig finlandssvensk variant? [but that a whole new world opened up for me. The combination men att - a sloppy and unnecessary Finland Swedish variant?]', in Marianne Nordman, Christer Laurén and Siv Björklun (eds.) Svenskan i Finland 6. Vaasa University. 104-116.

---. 2008. 'Constructing reasoning. The connectives för att (causal), så att (consecutive) and men att (adversative) in Swedish conversations', in Jaakko Leino (ed.) Constructional reorganization. Amsterdam: John Benjamins. 105-152.

Londen, Anne-Marie. 1997. 'Då e man ju fri liksom - Om användningen av partikeln liksom i ett finlandssvenskt radiosamtal [Then one is like free - On the use of the particle liksom in a Finland Swedish radio conversation]', in Saara Haapamäki (ed.) Svenskan i Finland 4. 101-118. 
Lyngfelt, Benjamin. 2003. 'Samordnande att - en talspråklig sambandsmarkör sedd från ett syntaktiskt perspektiv [Coordinating att - a conversational coherence marker seen from a syntactic perspective]', in Hans Landqvist, Sven-Göran Malmgren et al. (eds.) Texten framför allt. Festskrift till Aina Lundqvist på 65-årsdagen den 11 september 2003. Gothenburg University: Department of Swedish. 139-149.

Mithun, Marianne. 2008. 'The extension of dependency beyond the sentence.' Language 84(1). 69-119.

Nørgård-Sørensen, Jens. 2001. 'Plus at - en ny konjunktion i dansk [Plus at - a new conjunction in Danish]'. Danske Studier. 65-84.

ODS, Ordbog over det Danske Sprog [Dictionary of the Danish Language]. The Danish Language and Literature Society. Available online at http://ordnet.dk/ods (last accessed 25/09/2013).

Panther, Klaus-Uwe and Linda Thornburg. 2011. 'Emotion and desire in independent complement clauses. A case study from German', in Mario Brdar, Stefan Gries and Milena Žic Fuchs (eds.) Cognitive linguistics. Convergence and expansion. Amsterdam: John Benjamins. 87-114.

Petersson, David. 2011. 'Swedish exclamatives are subordinate'. Working Papers in Scandinavian syntax 88. 169-237.

SAOB. Svenska Akademiens Ordbok [Dictionary of the Swedish Academy]. Swedish Academy. Available online at http://g3.spraakdata.gu.se/saob/ (last accessed 25/09/2013).

Seppänen, Eeva-Leena and Ritva Laury. 2007. 'Complement clauses as turn continuations: The Finnish et(tä)-clause'. Pragmatics 17(4). 553-572.

Steensig, Jakob. 1998. 'Om fordi i forskellige sætningstyper i dansk talesprog [On fordi in different sentence types in everyday Danish conversation]', in Kjeld Kristensen, (ed.) Selskab for Nordisk Filologi København. Årsberetning 1996-1997. Copenhagen: Selskab for Nordisk Filologi. 179-192.

Stenström, Anna-Britta. 1998. 'From sentence to discourse: Cos (because) in teenage talk', in Andreas H. Jucker and Yael Ziv (eds.) Discourse markers. Amsterdam: Benjamins. 127146.

Teleman, Ulf, Staffan Hellberg and Erik Andersson. 2010. Svenska Akademiens grammatik [Grammar of the Swedish Academy]. $3^{\text {rd }}$ edn., 4 vol. Stockholm: Norsteds.

Thompson, Sandra. 2002. "Object complements" and conversation. Towards a realistic account'. Studies in Language 26(1). 125-164.

Verstraete, Jean-Christophe. 2004. 'Initial and final position for adverbial clauses in English: the constructional basis of the discursive and syntactic differences'. Linguistics 42(4), 819-853.

---. 2005. 'Two types of coordination in clause combining'. Lingua 115. 611-626.

---. 2007. Re-thinking the coordinate-subordinate dichotomy. Berlin: Mouton de Gruyter.

Verstraete, Jean-Christophe, Sarah D'Hertefelt and An Van linden. 2012. 'A typology of complement insubordination in Dutch'. Studies in Language 36(1). 123-153. 
Verstraete, Jean-Christophe and Sarah D'Hertefelt. Ms. 'Running in the family: Patterns of complement insubordination in Germanic'.

Zanuttini, Raffaella and Paul Portner. 2003. 'Exclamative clauses: At the syntax-semantics interface'. Language 79(1). 39-81. 